\title{
The DOCTRINe OF THE TRINITY IN THE EARLY CHURCH
}

\section{Book Title:}

A brief history of the doctrine of the Trinity in the early church

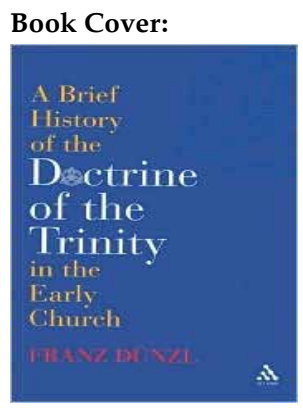

Author:

Franz Dünzl

Translated by:

John Bowden

Publisher:

T \& T Clark, Edinburgh,

2007 , pp. $148, \$ 26.95^{*}$

*Book price at time of Review

Review Title:

The doctrine of the Trinity in the early church

\section{Reviewer:}

Jan Muis

\section{Affiliation:}

${ }^{1}$ Protestant Theological

University, The Netherlands

email:

jmuis@pthu.nl

\section{Postal address:}

Protestant Theological

University, PO Box 80.105,

NL-3508 TC Utrecht, The

Netherlands

How to cite this book review:

Muis, J., 2010, 'The doctrine of the Trinity

in the early church', HTS Teologiese Studies/

Theological Studies 66(1),

Art. \#986, 2 pages. DOI:

10.4102/hts.v66i1.986

This review is available at:

http://www.hts.org.za

(c) 2010. The Authors. Licensee: OpenJournals Publishing. This work is licensed under the Creative Commons Attribution License.
In this rich work Franz Dünzl, Professor of Early Church History and Patristics at the University of Würzburg, gives an illuminating description of the theological, ecclesial and political developments that resulted in the formulation of the doctrine of the Trinity at the Council of Constantinople in 381. The book is elegantly written, offers a clear picture of the overall development of the discussions and at the same time does full justice to the intricate details of this 'impenetrable theological jungle' (p. 133). New names and concepts are elucidated in the text. The central documents of the discussion are cited, translated and interpreted in their original context. Ambiguous Greek and Latin theological terms, such as 'hypostasis', 'homoousios' and 'substantia' are clarified. How crucial biblical texts were understood by the various theological schools is highlighted as well. It is shown that many labels which became common in the theological jargon were designed by theologians in order to denounce their adversaries, not to accurately describe their positions; examples are 'ditheism', 'patripassianism', 'sabellianism' and 'arianism'. For these reasons, this volume not only serves as a very useful introduction for students in the history of doctrine, but also makes for stimulating reading for theologians wanting to sharpen and deepen their understanding of the trinitarian dogma.

According to Dünzl what trinitarian reflection tried to deal with, was how to combine biblical monotheism with the belief in Jesus Christ as the divine Savior and in the sanctifying Spirit (pp. 1-2). Initial interpretations of the relation between God and Jesus Christ were adoptianism, pneuma-christology and angel-christology (pp. 8-16). Irenaeus developed the concept of 'oikonomia' and described Christ and the Spirit metaphorically as the two 'hands' of God, but did not discuss their ontological status (p. 17). For Hellenistic theologians the notion of a 'logos' as mediating reality between God and the world was very attractive (pp. 21-25). After the logos-christology had become the dominant model, the discussion focused on the relation between the Logos and the Father. In general, the theologians of the Western part of the Roman Empire grounded their reflections on the one and only God ('monarchism'), whilst the Eastern theologians concentrated on the three divine hypostases as distinct realities. The Arian controversy concerned the interpretation of 'begetting' in Proverbs 8, 25: 'The Lord ... begets me'. The metaphor of begetting can be understood in many different ways (pp. 43, 56, 68, 90). At the Council of Nicea (325), the emperor Constantine tried to settle the issue, but the aftermath of Nicea showed that the ambiguous term 'homo-ousios', which is not the core statement of the creed of Nicea (p. 57), allowed for different interpretations. Besides orthodox 'homoousians' or 'old-nicenes', such as Athanasius and Marcellus of Ancyra, 'neo-arian', 'homoeouseans', 'homoeans' and 'neo-nicenes' can be distinguished (pp. 87-103). Dünzl repudiates the simplistic picture that the history from Nicea to Constantinople was the triumph of orthodoxy over heresy and convincingly argues that in the controversies between East and West truth can be found on both sides (pp. x, 20, 85, 135). The decisive breakthrough that made a new consensus between bishops of the East and of the West possible was the result of deep theological reflection: Basilius's distinction between the concepts of 'ousia' (Latin: 'substantia' or 'essentia') and 'hypostasis' ('person'), combined with the apophatic insight that God's essence cannot be grasped by the finite, human mind (pp. 106-109). The new consensus was formulated in the creed of Constantinople.

This is a fascinating story, but for a modern reader a strange one too. In a Hellenistic culture, the wisdom of Proverbs 8 came to be associated with the philosophical notion of a mediating 'logos' and this Logos was believed to be the pre-existent Son of God that became incarnate in Jesus Christ. On the basis of these identifications, a description of the relation between the pre-existent Son of God and the Father was found in the metaphor 'begetting' in Proverbs 8. However, for a modern reader of the Bible it is far from evident that this particular biblical text should be appropriate to understand the relation between God the Father and his Son Jesus Christ. For the early theologians, however, this text was crucial to the understanding of the ontological status of the pre-existent Son. The problem was how this metaphor could be conceptually explained. The neo-arian Aetius used 'begetting' as a univocal concept and understood the unbegottenness of God as his essence (p. 89). The homoiousians concluded from this metaphor that the substance of the Son was similar to the substance of the Father (pp. 90-91). Basil argued that the substance of God cannot be conceptually described at all (pp. 106-107).

In his concluding 'Prospect', Dünzl argues that the ontological and hermeneutical presuppositions of the early theologians are radically different from ours and that bridging the gulf between intellect and matter, transcendence and immanence, unity and diversity (p. 134) no longer poses a problem. This suggests that patristic theology can no longer guide our christological reflection. However, for some modern and post-modern theologians, patristic theology is very inspiring, precisely because of its nonmodern character. Examples are A. van de Beek's christology inspired by Athanasius (Jezus Kurios. De Christologie als hart van de theologie, Kampen 1998) and David Bentley Hart's refutation of postmodernist ontology on the basis of a trinitarian world-view inspired by Gregorius (Gregory) of Nyssa (The beauty of the infinite: The aesthetics of Christian truth, Grand Rapids Michigan 2003). Dünzl rightly argues that the problem of trinitarian thinking is basic for the Christian faith because the one and only God reveals himself in salvation history really as Father, Son and Spirit (p. 137). Moreover, he suggests that Jesus' salvation cannot be fully understood in terms of 'example' or 'substitution', but only in terms of 'unity' between Creator and his creation. Whether this understanding of salvation, which is passionately expounded by Hart, is based on an obsolete platonic ontology of participation (so Vincent Brümmer, Ultiem geluk. Een nieuwe kijk op Jezus, verzoening en Drie-eenheid, Kampen 2005, pp. 120-121, 125-128) 
requires further discussion. Dünzl concludes that the neo-nicene theology was successful

not because its exegesis was so convincing in every detail but because it found a viable way for its time of keeping the concerns of biblical monotheism in balance with the reality of Father, Son and Spirit which is also attested in the Bible, without locating the saviour and consummator of the creation on the side of the creatures.

(p. 138)

The trinitarian dogma is not a solution for all problems, but in our search for God it can point us in the right direction (p. 139). This 'short history' offers valuable historical information and insight and stimulates systematic reflection. A marvellous book. 